\title{
Multi-Disciplinary Assessment of Napier Grass Plantation on Local Energetic, Environmental and Socioeconomic Industries: A Watershed-Scale Study in Southern Thailand
}

\author{
Kotchakarn Nantasaksiri $^{1, *(\mathbb{D})}$, Patcharawat Charoen-amornkitt ${ }^{2}$ (D) Takashi Machimura $^{1}$ (D) and Kiichiro Hayashi ${ }^{3}$ \\ 1 Division of Sustainable Energy and Environmental Engineering, Graduate School of Engineering, \\ Osaka University, Osaka 565-0871, Japan; mach@see.eng.osaka-u.ac.jp \\ 2 Department of Mechanical Engineering, Faculty of Engineering, King Mongkut's University of Technology Thonburi, \\ Bangkok 10140, Thailand; patcharawat.@gmail.com \\ 3 Institute of Materials and Systems for Sustainability, Nagoya University, Nagoya 464-8601, Japan; \\ maruhaya98-@nagoya-u.jp \\ * Correspondence: kotchakarn@ge.see.eng.osaka-u.ac.jp
}

\section{check for} updates

Citation: Nantasaksiri, K. Charoen-amornkitt, P.; Machimura, T.; Hayashi, K. Multi-Disciplinary Assessment of Napier Grass Plantation on Local Energetic, Environmental and Socioeconomic Industries: A Watershed-Scale Study in Southern Thailand. Sustainability 2021, 13, 13520. https://doi.org/ $10.3390 /$ su132413520

Academic Editor: Christian N. Madu

Received: 5 November 2021

Accepted: 2 December 2021

Published: 7 December 2021

Publisher's Note: MDPI stays neutral with regard to jurisdictional claims in published maps and institutional affiliations.

Copyright: (c) 2021 by the authors. Licensee MDPI, Basel, Switzerland. This article is an open access article distributed under the terms and conditions of the Creative Commons Attribution (CC BY) license (https:/ / creativecommons.org/licenses/by/ $4.0 /)$.

\begin{abstract}
Napier grass is an energy crop that is promising for future power generation. Since Napier grass has never been planted extensively, it is important to understand the impacts of Napier grass plantations on local energetic, environmental, and socioeconomic features. In this study, the soil and water assessment tool (SWAT) model was employed to investigate the impacts of Napier grass plantation on runoff, sediment, and nitrate loads in Songkhla Lake Basin (SLB), southern Thailand. Historical data, collected between 2009 and 2018 from the U-tapao gaging station located in SLB were used to calibrate and validate the model in terms of precipitation, streamflow, and sediment. The simulated precipitation, streamflow, and sediment showed agreement with observed data, with the coefficients of determination being $0.791,0.900$, and 0.997 , respectively. Subsequently, the SWAT model was applied to evaluate the impact of land use change from the baseline case to Napier grass plantation cases in abandoned areas with four different nitrogen fertilizer application levels. The results revealed that planting Napier grass decreased the average surface runoff and sediment in the watershed. A multidisciplinary assessment supporting future decision making was conducted using the results obtained from the SWAT model; these showed that Napier grass will provide enhanced benefits to hydrology and water quality when nitrogen fertilizers of 0 and $125 \mathrm{kgN} \mathrm{ha}^{-1}$ were applied. On the other hand, the benefits to the energy supply, farmer's income, and $\mathrm{CO}_{2}$ reduction were highest when a nitrogen fertilization of $500 \mathrm{kgN} \mathrm{ha}^{-1}$ was applied. Nonetheless, planting Napier grass should be supported since it increases the energy supply and creates jobs while also reducing surface runoff, sediment yield, nitrate load, and $\mathrm{CO}_{2}$ emission.
\end{abstract}

Keywords: SWAT model; water quality; hydrology; fertilizer application; Songkhla Lake Basin

\section{Introduction}

The increase in fossil-fuel-based energy consumption has resulted in an energy crisis and a critical state of global warming in the 21st century. Finding a new energy source that is renewable, clean, and sustainable has thus become an urgent task. Among the candidates suitable for such clean energy, biogas, which is a gaseous fuel obtained from the decomposition of organic matter, has received widespread attention [1-3]. Biogas feedstocks can be found in a variety of forms, such as agricultural residues, forestry byproducts, animal waste, and dedicated energy crops. Biogas energy derived from dedicated energy crops can be considered carbon-neutral because although carbon is released during the process of power generation, the same amount of carbon is absorbed by the crops during their growth. The advantages of biogas are not limited to carbon neutrality - it also has higher yields and a shorter life cycle, thus promising a stable fuel supply. However, for the widespread use 
of these renewable energy crops, there are several aspects to be considered prior to making decisions regarding land use change for energy plantations, in order to avoid unforeseen socioeconomic and environmental issues [4-7].

Utilizing bioenergy can directly satisfy the Sustainable Development Goals (SDGs) suggested by the United Nations Development Programme (UNDP), namely, SDG 7 (affordable and clean energy), SDG 8 (decent work and economic growth), and SDG 13 (climate action). However, there are several SDGs that are indirectly related to the use of bioenergy, since planting new dedicated energy crops would affect water and land. For example, SDG 6 ensures safe and affordable drinking water and freshwater supplies, while SDG 15 conserves and restores terrestrial and freshwater ecosystems. This highlights the importance of a multidisciplinary assessment for the safe introduction of bioenergy as an alternative energy source.

Napier grass (Cenchrus purpureus Schumach.) is one of the popular perennial grasses used in biogas-based power generation [8-13]. It possesses many desirable characteristics for energy crops, such as a short life cycle, relatively high methane content, and high water use efficiency [14-16]. Additionally, it has been reported that perennial grasses can help reduce nitrate transport into the soil, which is a waterborne pollutant [17]. Furthermore, Napier grass can grow well under flooded soil conditions, making it suitable for use in water pollution treatment [18]. Although Napier grass can serve as an alternative fuel source and reduce carbon emissions, there are concerns over the impacts of such a crop on the local soil and water, due to changes in land use and intensive agricultural practices [19-21].

To investigate the impacts of land use changes on the local soil and water, the soil and water assessment tool (SWAT) model is one of the most promising models. Dos Santos et al. [22] utilized the SWAT model to investigate the impacts of land use changes on streamflow and sediment yield and discuss ways to consider future land use conditions in the Atibiai River basin, Brazil. The results provided useful information for proposing improvements in the basin's environmental quality and management. The SWAT model was also applied to assess the impact of changes in agricultural management practices on nitrate loads by Epelde et al. [23]. They found that the trends of nitrogen surplus in the system generally increased as the fertilization input increased. The effects of replacing conventional crops with Miscanthus on riverine nitrate load were investigated by Ng et al. [24] using the SWAT model. The results revealed that the nitrate load tended to decrease when replacing conventional crops with Miscanthus. Similarly, using the SWAT model, Cibin et al. [25] investigated the impacts of bioenergy crops on hydrology and water quality. The study also found that perennial grass reduced pollutant load at the watershed outlet. This suggested that the study on the impacts of land use changes on the local soil and water is currently of interest.

In our previous study that evaluated the land potential for Napier grass cultivation, the dry matter yield (DMY) was estimated using the SWAT model [26]. The SWAT model successfully estimated the Napier grass DMY in Thailand, with a coefficient of determination of 0.951; the results also show that southern Thailand had the highest average DMY. In our continued study [27], we integrated the land suitability map, obtained from a multicriteria decision analysis, and the spatial distribution of DMY to assess the suitability of a site for Napier-grass-based biogas power plants in southern Thailand. The location of biogas power plants and their distance from roads, residential areas, waterbodies, their access to the electricity grid, and their supply of feedstock were all considered during the site suitability analysis. The results revealed that, using only Napier grass from abandoned areas, five biogas power plants could be built with a total contracted capacity of 420 MW. This highlights that Napier grass can significantly reduce Thailand's dependency on imported electricity.

Although Nantasaksiri et al. [26,27] suggested that Napier grass possesses massive potential in biogas-based power generation in southern Thailand, with a few socioeconomic and environmental criteria considered, a study on the impacts of Napier grass on hydrology and water quality is yet to be performed. Moreover, the factors to be considered should not be limited to hydrology and water quality because there are several varied 
parties involved: The government will likely focus on energy supply, $\mathrm{CO}_{2}$ reduction, and sustainability, while the local community and farmers are likely most interested in job creation and income. Hence, the broad objective of this study was to investigate the effects of different management practices for Napier grass plantations on surface runoff, sediment yield, and nitrate load in southern Thailand using the SWAT model. Based on the results obtained, a multidisciplinary assessment for supporting adequate decision making to utilize Napier grass as a feedstock for biogas-based power generation was carried out to comparatively assess the advantages and disadvantages of various cases of cultivation practices with different fertilizing levels. The results from this study provide a logical framework to support decision making for implementing new dedicated energy crops as a biogas feedstock, which is useful for the transition toward a renewable and sustainable energy society.

\section{Materials and Methods}

\subsection{Study Site}

The Songkhla Lake Basin (SLB), shown in Figure 1, was selected as the study site since our previous study had found three potential sites suitable for biogas-based power plants here [27]. This basin is located in southern Thailand and lies within three provinces, namely, Phattalung, Songkhla, and Nakhonsithammarat, and has an area of approximately $8157 \mathrm{~km}^{2}$. The elevation of the watershed ranges from 0 to $1334 \mathrm{~m}$ above sea level, and the average annual precipitation is $1992 \mathrm{~mm}$. In this watershed, the annual average temperature is $27.4^{\circ} \mathrm{C}$; the highest average temperature $\left(33.9^{\circ} \mathrm{C}\right)$ was observed in April, and in October, the average temperature was found to be lowest $\left(23.0^{\circ} \mathrm{C}\right)$. The average relative humidity for the SLB was $81.0 \%$. The major land uses in the basin are agricultural $(60.46 \%)$, forest $(13.79 \%)$, and water bodies (13.54\%). Southern Thailand is famous for latex production, and $41.33 \%$ of the total area in this basin is utilized for the Pará rubber tree plantation. The largest natural lake in Thailand, i.e., Songkhla Lake, is located in the SLB. Among the chain of lagoons that form Songkhla Lake, the northernmost lagoon, i.e., Thale Noi, was declared a protected freshwater wetland in 1975. In addition, the Kuan Ki Sian knoll in the non-hunting area was declared a wetland of international importance in 1998 by the Ramsar Convention. Approximately 1.5 million people live in the basin, resulting in the rapid degradation of natural resources in the area because of economic activities. Because many parts of the SLB are wetlands, the area is highly susceptible to flooding and landslides, and several studies have focused on combating these issues [28,29].

\subsection{Model Description}

The SWAT model, a continuous time- and process-based watershed model, was used to examine the impacts of Napier grass plantations on the hydrology and water quality within SLB. A detailed description of the SWAT model used for calculating Napier grass DMY can be found in our previous study [26]. Based on the SWAT theoretical documentation [30], surface runoff, sediment yield, and nitrate load, which are considered indicators of environmental burdens corresponding to flood, erosion, and water pollution, respectively, were calculated. The surface runoff $Q_{\text {surf }}\left(\mathrm{mm} \mathrm{day}^{-1}\right)$ is described using the following equation:

$$
Q_{\text {surf }}=\frac{\left(R_{\text {day }}-0.2 S\right)^{2}}{R_{\text {day }}+0.8 S}
$$

where $R_{\text {day }}$ is the rainfall depth for the day $\left(\mathrm{mm} \mathrm{day}^{-1}\right)$ and $S$ is the retention parameter $\left(\mathrm{mm}\right.$ day $\left.^{-1}\right)$, which is defined as:

$$
S=25.4\left(\frac{1000}{C N}-10\right)
$$


where $C N$ is the curve number for the day. The curve number $C N$ is an important parameter for calculating surface runoff, depending on the hydrologic soil group and land use. In the SWAT model, a higher curve number indicates a higher runoff potential, and a lower number indicates greater retention.

To calculate sediment yield sed (in metric tons), the modified Universal Soil Loss Equation (MUSLE) equation was used. In this approach, the sediment yield is a function of the surface runoff $Q_{\text {surf }}$. The MUSLE equation can be expressed as:

$$
\text { sed }=11.8\left(Q_{\text {surf }} q_{\text {peak }} A_{\text {hru }}\right)^{0.56} \text { K.C.P.LS.CFRG }
$$

where $q_{\text {peak }}$ is the peak runoff rate $\left(\mathrm{m}^{3} \mathrm{~s}^{-1}\right), A_{\text {hru }}$ is the area of the hydrological response unit (HRU) (ha), $K$ is the USLE soil erodibility factor, $C$ is the USLE cover and management factor, $P$ is the USLE support practice factor, $L S$ is the USLE topographic factor, and CFRG is the coarse fragment factor.

The total nitrate content assessed in the SWAT model is an integrated contribution of fertilizer, manure application, bacterial attachment, mineralization, atmospheric deposition, plant uptake, leaching, volatilization, denitrification, and erosion. Because there are several equations involving calculations of the nitrate cycle, the SWAT model's description was carefully summarized by Hass et al. [31], which will not be repeated here. The total nitrate balance in a period, $\Delta N\left(\mathrm{kgN} \mathrm{ha}^{-1}\right)$, was calculated using Equation (4), i.e., the difference between nitrate input into the nitrate pool and the nitrate used by agricultural activities:

$$
N=\left(N_{\text {fert }}+N_{\text {hum }}+N_{\text {min }}+N_{\text {atm }}\right)-\left(N_{\text {denit }}+N_{\text {up }}+N_{\text {leach }}+N_{\text {surf }}+N_{\text {latf }}\right)
$$

where $N_{\text {fert }}$ is the amount of nitrate in fertilizers, $N_{h u m}$ is the nitrogen mineralization from the humus active organic nitrogen pool (the amount of nitrogen moving from the active organic to nitrate pool in the watershed), $N_{\min }$ is the nitrogen mineralization of the fresh organic nitrogen pool (the amount of nitrogen moving from fresh organic, i.e., residue to the nitrate pool in the watershed), $N_{a t m}$ is the nitrate from atmospheric deposition, $N_{\text {denit }}$ is the nitrate from denitrification, $N_{\text {leach }}$ is nitrate percolation through the bottom layer of the soil profile in the watershed, $N_{\text {surf }}$ is the nitrate loading to stream in the surface runoff in the watershed, and $N_{\text {lat } f}$ is the nitrate loading to stream in the lateral flow in the watershed. The unit of all the above terms is in $\mathrm{kgN} \mathrm{ha}^{-1}$.

Hass et al. [31] found that the nitrogen uptake distribution, or $\beta_{n}$, was strongly correlated with the nitrate concentration in crops. In the periods of increased nitrate uptake by plants in the root zone, the dominant phases of the nitrogen uptake distribution $\beta_{n}$ were observed, which indicated that the crops consumed nitrate. SWAT calculates the nitrogen removed from the soil by plants by taking nitrogen from the nitrate pool [30]. If the nitrates in the upper layers of the soil was insufficient, the nitrates in the root zone were allowed to fully compensate for it. The actual amount of nitrogen removed from the soil, $N_{\text {actualup, }}$, is calculated using Equation (5):

$$
N_{\text {actualup }, l y}=\min \left[N_{u p, l y}+N_{\text {demand }}, N O 3_{l y}\right]
$$

with:

$$
N_{u p, l y}=N_{u p, z l}-N_{u p, z u}
$$

where $N_{u p, l y}$ is the potential nitrogen uptake for layer $l y\left(\mathrm{kgN} \mathrm{ha}^{-1}\right), N_{\text {demand }}$ is the nitrogen uptake demand not met by overlying soil layers $\left(\mathrm{kgN} \mathrm{ha}^{-1}\right), N O 3_{l y}$ is the nitrate content of the soil layer $l y\left(\mathrm{kgN} \mathrm{ha}^{-1}\right), N_{u p, z l}$ is the potential nitrogen uptake from the soil surface to the lower boundary of the soil layer $\left(\mathrm{kgN} \mathrm{ha}^{-1}\right)$, and $N_{u p, z u}$ is the potential nitrogen uptake from the soil surface to the upper boundary of the soil layer $\left(\mathrm{kgN} \mathrm{ha}^{-1}\right)$. 
To calculate the potential nitrate uptake $N_{u p, z}$, from the soil surface to the depth $z$, Equation (6) is used:

$$
N_{u p, z}=\frac{N_{u p}}{\left[1-\exp \left(-\beta_{n}\right)\right]}\left[1-\exp \left(-\beta_{n} \cdot \frac{z}{z_{\text {root }}}\right)\right]
$$

with:

$$
N_{u p}=\min \left[b i o_{N, o p t}-b i o_{N}, 4 f r_{N, 3} \Delta b i o\right]
$$

and

$$
\text { bio }_{N, o p t}=f r_{N} b i o
$$

where $N_{u p}$ is the potential nitrogen uptake $\left(\mathrm{kgN} \mathrm{ha}^{-1}\right), \beta_{n}$ is the nitrogen uptake distribution parameter, $z$ is the depth from the soil surface $(\mathrm{mm}), z_{\text {root }}$ is the depth of root development into the soil $(\mathrm{mm}), b^{2} o_{N, o p t}$ is the optimal mass of nitrogen stored in plant material for the current growth stage $\left(\mathrm{kgN} \mathrm{ha}^{-1}\right), b i o_{N}$ is the actual mass of nitrogen stored in plant material $\left(\mathrm{kgN} \mathrm{ha}^{-1}\right), f r_{N}$ is the normal fraction of nitrogen in the plant biomass, $\Delta$ bio is the potential increase in total plant biomass on a given day $\left(\mathrm{kg} \mathrm{ha}^{-1}\right)$, bio is the total plant biomass on a particular day $\left(\mathrm{kg} \mathrm{ha}^{-1}\right)$, and subscript 3 indicates the maturity growth tage.

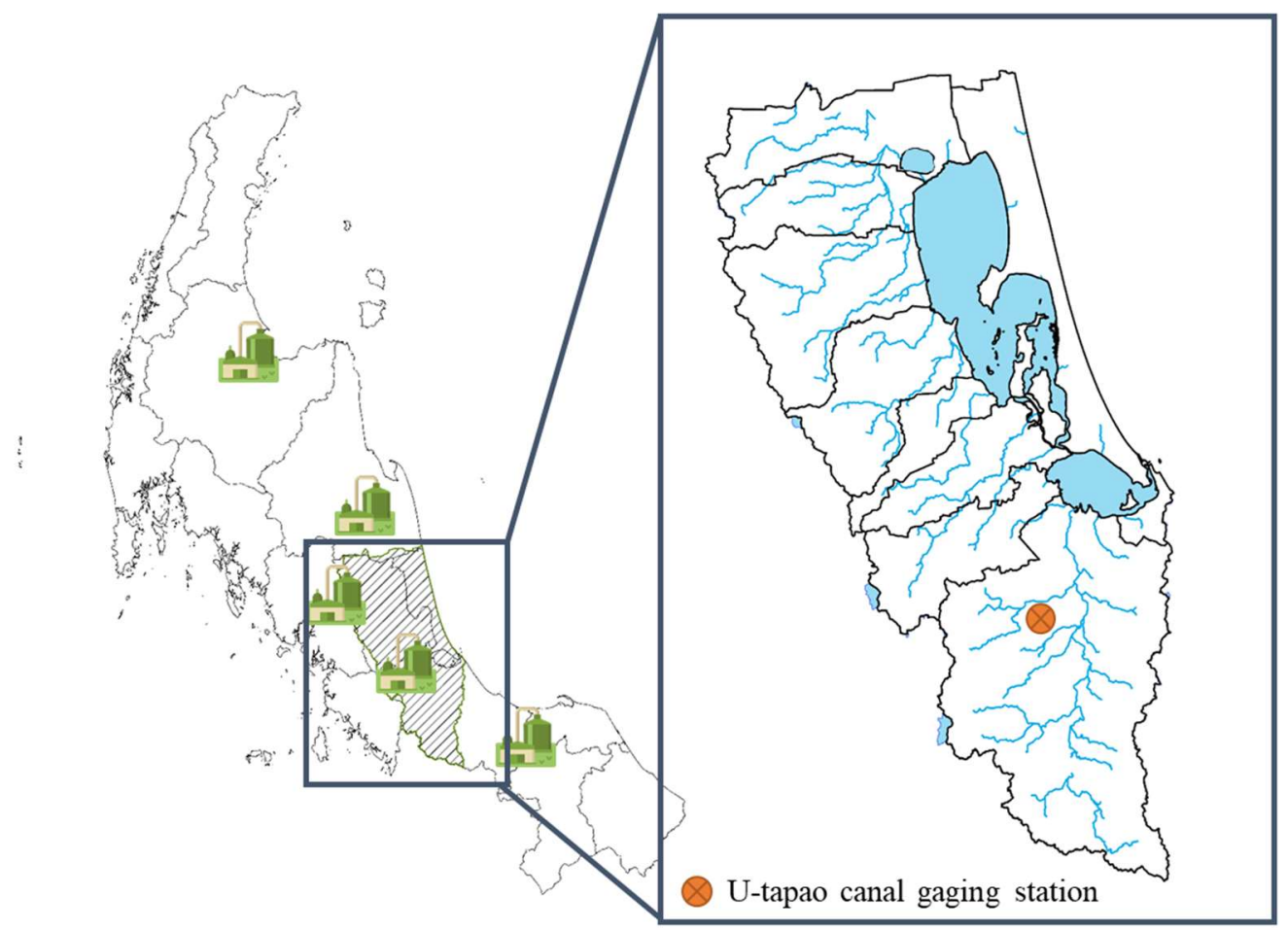

Figure 1. Map of the study area (Songkhla Lake Basin) in southern Thailand and the location of U-tapao canal gauging station.

\subsection{Data Used}

For ease of calculation, the watershed was divided into small units called HRUs. An HRU is the smallest spatial unit that consists of a unique load combination of land use, soil type, and slope. Figure 2 display the geographical data used in this study, including land use and elevation. To determine the slope, slope length, and stream network of each basin, digital elevation model (DEM) data with a resolution of $30 \mathrm{~m}$ was extracted from CGIAR CSI [32], as shown in Figure 2a. The topographical map thus obtained needed to be integrated with soil and land use maps to obtain HRUs in the area of interest. To integrate these data, all maps were converted to a raster dataset with a resolution of $50 \mathrm{~m}$. The spatial distribution of soil types was provided by the FAO-UNESCO harmonized 
world soil database [33]. Figure $2 \mathrm{~b}$ displays the land use map from the Land Development Department (LDD) of Thailand used in this study. To calculate plant growth and water and nitrate cycles occurring in the watershed, weather data from the National Centers for Environmental Prediction (NCEP) called Climate Forecast System Reanalysis (CFSR) [34] were used, which was recommended by SWAT developers and various studies utilized to predict crop production, streamflow, sediment yield, and nitrate load [35-37]. These data include the maximum and minimum temperatures, precipitation, solar radiation, and wind speed. Since the data from NCEP were available only from 1979 to 2014, a daily weather generator algorithm (dGEN) of the SWAT model was used to generate weather data during the rest of the calculation period. The CFSR data are provided on a Gaussian grid, defined by the NCEP, with a horizontal resolution of $38 \mathrm{~km}\left(0.3125^{\circ}\right)$; the vertical resolution was not equally spaced. By combining the abovementioned data, we obtained ready-to-use data of the watershed of interest.



Figure 2. Maps of (a) elevation and (b) land use in Songkhla Lake Basin.

\subsection{Model Calibration and Validation}

To obtain a reliable prediction, the model must be carefully calibrated and validated. The main focus of this study was to investigate the effects of Napier grass plantations on hydrology and water quality; hence, streamflow and sediment yield observations were used for the calibration and validation. Since weather data greatly affected the simulation outputs, and since it is unclear if the weather data, including the maximum and minimum temperature, precipitation, solar radiation, and wind speed, generated by dGEN resembled the actual historical data, precipitation was also included in the calibration and validation processes. Only precipitation was selected for the process because it significantly affected the simulation outputs of the hydrological model, and because precipitation observation data were available. Although there are several gauging stations in the Songkhla basin, data on the hydrology, water quality, and precipitation of most stations are not publicly available. To the best of our knowledge, the only station that can be readily accessed for streamflow, sediment yield, and precipitation data is the U-tapao canal gaging station $\left(6^{\circ} 55^{\prime} 52.32^{\prime \prime} \mathrm{N}, 100^{\circ} 26^{\prime} 24.72^{\prime \prime}\right.$ E, see Figure 1). Therefore, the monthly streamflow, sediment yield, and precipitation data from the station during 2009-2018 were used for calibration and validation. 
For simulation using the SWAT model, there were several parameters affecting hydrology, water quality, and precipitation, and approximately 13 parameters exist that are related to the output of interest. With such a large number of parameters, it is difficult to perform manual calibration. Therefore, to perform the calibration, four steps were used to adjust the parameters. In the first step, previous studies $[22,23,38,39]$ were reviewed to identify a range of parameters and sensitive parameters. Then, as a starting point, a simulation was performed using the default values suggested by the SWAT. Subsequently, the sensitive parameters were calibrated manually, similar to the manual calibration in Mengistu et al. [40] and Arnold et al. [41], except for the curve number that dos Santos et al. [22] suggested for multiplying the default numbers by 0.7 . Finally, when needed, the input parameters were re-adjusted within reasonable parameter ranges obtained from the first step, and the process was repeated until satisfactory results were obtained. The coefficient of determination $\left(R^{2}\right)$ of streamflow, sediment yield, and precipitation was used as an objective function, and the criterion for judging the quality of calibration was to identify the set of parameters that improved $R^{2}$ of all outputs to the desirable value of 0.70 . The calibrated values are presented in Table 1. After a set of reliable parameters was obtained, the SWAT model was validated using three statistical parameters: the Nash-Sutcliffe model efficiency index (NSE), percent bias (PBIAS), and $\mathrm{R}^{2}$.

Table 1. Summary of calibrated SWAT parameters.

\begin{tabular}{|c|c|c|c|c|c|c|c|}
\hline & Parameter & File & Description (Unit) & Default Range & $\begin{array}{c}\text { Previous Studies } \\
{[33-36]}\end{array}$ & Default Value & Calibrated Value \\
\hline \multirow{9}{*}{ 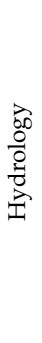 } & $\mathrm{CN} 2$ & mgt & SCS runoff curve number & $0-100$ & Default $\times 0.7$ & $\begin{array}{l}\text { depends on } \\
\text { soil and } \\
\text { land use }\end{array}$ & $55-69$ \\
\hline & ESCO & .hru & Soil evaporation compensation factor & $0-1$ & $0.6-0.9$ & 1 & 0.9 \\
\hline & CANMX & hru & Maximum canopy storage $(\mathrm{mm})$ & $0-100$ & $15-80$ & 0 & 20 \\
\hline & ALPHA_BF &.$g w$ & Baseflow recession constant & $0.0071-0.0161$ & $0.01-0.048$ & 0.048 & 0.048 \\
\hline & GW_REVAP &.$g w$ & Ground water revap coefficient & $0-0.4$ & $0.13-0.04$ & 0.003 & 0.04 \\
\hline & GW_DELAY & gw & Ground water delay (days) & $0-500$ & $14-500$ & 31 & 14 \\
\hline & REVAPMN &.$g w$ & $\begin{array}{c}\text { Threshold depth of water in shallow aquifer for } \\
\text { revap to occur }\end{array}$ & $0-1000$ & $250-500$ & 750 & 500 \\
\hline & EVRCH &.$b s n$ & Reach evaporation adjustment factor & $0.5-1$ & $0.5-0.9$ & 1 & 0.9 \\
\hline & SURLAG & .bsn & Surface runoff lag coefficient & $0.05-24$ & 15 & 4 & 15 \\
\hline \multirow{4}{*}{ 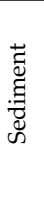 } & SPCON & .bsn & $\begin{array}{l}\text { Linear parameter for calculating the maximum } \\
\text { amount of sediment that can be re-entrained } \\
\text { during channel sediment routing }\end{array}$ & $0.0001-0.01$ & $0.001-0.008$ & 0.0001 & 0.001 \\
\hline & LAT_SED & .hru & $\begin{array}{l}\text { Sediment concentration in lateral flow and } \\
\text { groundwater flow }\end{array}$ & $0-5000$ & $5.7-3000$ & 0 & 3000 \\
\hline & CH_COV1 & .rte & Channel erodibility factors & $0-0.6$ & $0.1-0.17$ & 0 & 0.1 \\
\hline & CH_COV2 & .rte & Channel cover factors & $0-1$ & $0.1-0.6$ & 0 & 0.6 \\
\hline 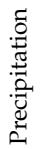 & rexp & - & The exponent of the exponential distribution & $1.0-2.0$ & - & - & 1.3 \\
\hline
\end{tabular}

\subsection{Napier Grass Plantation Cases and Calculation Setting}

The land use in the SLB at present (i.e., the baseline) and in case of Napier grass plantation are shown in Table 2. The non-hunting area must be preserved, and thus cannot be used for planting Napier grass. To avoid conflicts with existing industrial, urban, economical, and agricultural lands, only abandoned areas were considered for Napier grass plantations It should be noted that land used for agricultural purposes was found to decrease because those areas were considered abandoned agricultural lands by the LDD. 
Table 2. The area of land use types in the baseline case, which is current agricultural land use, and the cases where the abandoned areas were utilized to plant Napier grass in Songkhla Lake Basin.

\begin{tabular}{|c|c|c|c|c|c|}
\hline \multirow{2}{*}{ Land Use Type } & \multicolumn{2}{|c|}{ Baseline Case } & \multicolumn{2}{|c|}{ Napier Grass Case } & \multirow{2}{*}{$\%$ Change } \\
\hline & Area (ha) & $\%$ & Area (ha) & $\%$ & \\
\hline Rice & $118,769.9$ & 14.6 & $113,769.9$ & 13.9 & -4.2 \\
\hline Rubber Trees & $347,112.5$ & 42.6 & $337,112.5$ & 41.3 & -2.9 \\
\hline Oil Palm & 5592.5 & 0.7 & 5592.5 & 0.7 & 0.0 \\
\hline Agricultural Land & $31,624.8$ & 3.9 & $28,624.8$ & 3.5 & -9.5 \\
\hline Forest-Mixed & $112,485.4$ & 13.8 & $112,485.4$ & 13.8 & 0.0 \\
\hline Residential-Med/Low Density & $46,483.2$ & 5.7 & $46,483.2$ & 5.7 & 0.0 \\
\hline Water & $110,469.8$ & 13.5 & $110,469.8$ & 13.5 & 0.0 \\
\hline Miscellaneous area & 2394.9 & 0.3 & 2394.9 & 0.3 & 0.0 \\
\hline Abandoned area & $40,800.5$ & 5.0 & 0 & 0.0 & -100.0 \\
\hline Napier grass & 0.0 & 0.0 & $58,800.5$ & 7.2 & - \\
\hline Total area & $815,733.5$ & 100.0 & $815,733.5$ & 100.0 & \\
\hline
\end{tabular}

Since the growth of Napier grass is highly dependent on management practices [42], particularly on the amount of nitrogen fertilizer applied, a total of four cases were formulated, in each of which the amount of the applied nitrogen fertilizer varied from 0 to $500 \mathrm{kgN} \mathrm{ha}^{-1}$, at four levels. These values were obtained from studies by the Animal Nutrition Division, the Department of Livestock Development, and the Ministry of Agriculture and Cooperatives, and were published between 1993 and 2005 [43-51]. It was found that nitrogen fertilizer could increase Napier grass DMY by up to three times the DMY without the fertilizer [43-51]. However, it is unclear if such a large amount of fertilizer negatively impacts the environment in any way. The purpose of this variation was to investigate the impact of such an intensive fertilizer. These cases were applied to the ready-to-use data for the watershed of interest (as described above) to evaluate the impacts of different nitrogen fertilizer levels on Napier grass DMY, streamflow, sediment yield, and nitrate load.

In this study, the calibration period was from 2009 to 2013, while data from 2014 to 2018 were used for validation. Five warm-up years were used in the model initialization, as suggested by Tudose et al. [52], and the investigation was carried out over 10 years. Since the preset parameters for Napier grass plantation did not exist in the original SWAT model, a parameter set for predicting Napier grass crop yield must be developed. The simulation setup, model calibration, and validation were described in our previous study [26] and will not be repeated here. Since the models for other land uses were well established, the default setups for each land use suggested by SWAT were applied, except for the abandoned and miscellaneous areas that were not defined in SWAT. These areas were assumed to have a low agricultural area based on but the fact that little agricultural activity has been observed in the area. Changes between the parameter set of abandoned land and Napier grass cultivation are listed in Table 3.

Table 3. SWAT model parameters for abandoned land and Napier grass cultivation.

\begin{tabular}{|c|c|c|c|c|}
\hline Category & Parameter & Definition & Abandoned Land & Napier Grass \\
\hline \multirow{4}{*}{ Land cover/plant } & IDC & Land cover/plant classification & 6 (perennial) & 6 (perennial) \\
\hline & BIO_E & Radiation use efficiency & 30 & 38 \\
\hline & CHTMX & Maximum canopy height (m) & 0.9 & 2.5 \\
\hline & RDMX & Maximum root depth $(\mathrm{m})$ & 1.3 & 2.2 \\
\hline \multirow[b]{2}{*}{ Runoff } & CANMX & Maximum canopy storage (mm) & 20 (calibrated) & 20 \\
\hline & $\mathrm{CN}$ & Curve number & 65 (calibrated) & 55 \\
\hline Sediment & USLE_C & Minimum USLE crop factor & 0.003 & 0.003 \\
\hline \multirow{3}{*}{ Fertilizer } & FMINN & $\begin{array}{l}\text { Fraction of mineral } \mathrm{N}\left(\mathrm{NO}_{3} \text { and } \mathrm{NH}_{4}\right) \text { in fertilizer } \\
(\mathrm{kg} \text { min- } \mathrm{N} / \mathrm{kg} \text { fertilizer })\end{array}$ & 0 & 0.46 \\
\hline & FORGN & Fraction of organic $\mathrm{N}$ in fertilizer (kg org-N/kg fertilizer) & 0 & 0 \\
\hline & FNH3N & $\begin{array}{l}\text { Fraction of mineral } \mathrm{N} \text { in fertilizer applied as ammonia } \\
\qquad(\mathrm{kg} \mathrm{NH}-\mathrm{N} / \mathrm{kg} \text { fertilizer })\end{array}$ & 0 & 0 \\
\hline
\end{tabular}




\subsection{Multidisciplinary Assessment Supporting Decision Making for Utilizing Napier Grass}

Since solely considering the impact of Napier grass plantations on land is insufficient for decision making, this study considers impacts such as energy supply, carbon reduction, and benefits to farmers, in addition from hydrological impacts, in order to provide a better overview for decision making. From the simulation results obtained from the SWAT model, Napier grass DMY was utilized to evaluate energy supply, carbon reduction, and farmer benefits.

For energy supply, based on our previous study [27], approximately $11.1 \mathrm{kt-DMY}$ was required for generating $1 \mathrm{MW}$ of electricity. This is based on the assumption that a methane yield of $242 \mathrm{~m}^{3}$ can be obtained from 1 ton of Napier grass DMY [9]. In addition, a methane energy density of $40 \mathrm{MJ} \mathrm{m}^{-3}$ [53] and an energy conversion efficiency of $30 \%$ was assumed; the potential power generation could be conveniently evaluated using a factor of $11.1 \mathrm{kt}-\mathrm{DMY} \mathrm{MW}^{-1}$. Beyond the benefit of obtaining electricity, Napier-grass-based power generation could serve as a substitute for conventional power generation derived from fossil fuels. In a previous study [54], by utilizing Napier-grass-derived natural gas for electric generation instead of fossil fuels, approximately $60 \%$ of $\mathrm{CO}_{2}$ emissions could be reduced (i.e., from 1080 to $450 \mathrm{kgCO}_{2} \mathrm{MWh}^{-1}$ ). Therefore, the $\mathrm{CO}_{2}$ reductions were estimated by multiplying the derived power generation by the reduced $\mathrm{CO}_{2}$ emissions.

Using Napier grass as a biogas feedstock not only helps reduce $\mathrm{CO}_{2}$ emissions but also provides benefits to farmers. Currently, the Napier grass purchase price in Thailand is approximately 300 Baht (t-fresh biomass) ${ }^{-1}$ (equivalent to 1500 Baht t-DMY ${ }^{-1}$ ). Further-

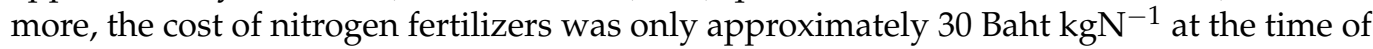
this study. This is a relatively high purchase price with a relatively low additional cost and, thus, it was encouraging for farmers to aim to achieve more production per area. This could lead to environmental problems owing to the overutilization of nitrogen fertilizers. Therefore, the tradeoff between Napier grass production and nitrate loads should be carefully considered. The main purpose of this work is to investigate the impact of different applied fertilizer inputs on additional revenue. The money spent on fertilizers was deducted from the Napier grass selling price to evaluate the farmer's operating income under different management practices.

After all impacts, including surface runoff, sediment yield, nitrate load, energy supply, carbon reduction, and benefits to farmers, were determined in each case, they were scaled using max-min normalization to make it convenient for comparison. The max and min values were set to 1.0 and 0.5 , respectively. The comparison was performed using a radar chart to enhance visibility.

\section{Results and Discussion}

\subsection{Model Calibration and Validation}

Figure 3 show the goodness-of-fit plots for the monthly streamflow, sediment yield, and precipitation, with the initial and final parameter sets in the calibration period from 2009 to 2013. Using the manual calibration process mentioned above, the $R^{2}$ of the streamflow increased from 0.476 to 0.714 , as depicted in Figure 3a. For the sediment yield, the $\mathrm{R}^{2}$ of 0.828 from the default parameter set was improved to 0.957 (see Figure 3b). The initial parameter set provided a reasonable prediction for precipitation, as an $R^{2}$ of 0.476 was initially achieved. However, the accuracy can be further improved after calibration, and an $R^{2}$ of 0.806 was obtained. It can be seen that the data on the top right in the $F$ are quite far from most of the values presented in the figure. This is due to the fact that, in the wet season, the amount of precipitation is usually higher as compared to the rest of the year. Although they seem to be outliers in Figure 3, considering all the data used in the study (2005-2018, including the warm-up years), these events occurred once in a while and are normally found. It should be noted that some points are over/underpredicted and shifted as the model predicted that the event would occur one month before or after the actual event (see Figure 4). However, since the objective of this study is to estimate the long-term impacts of Napier grass plantation, the annual average of the results is sufficient for the 
estimation. Overall, it is clear that predictions can be satisfactorily improved by using the manual calibration process; Table 1 displays the final parameter set.
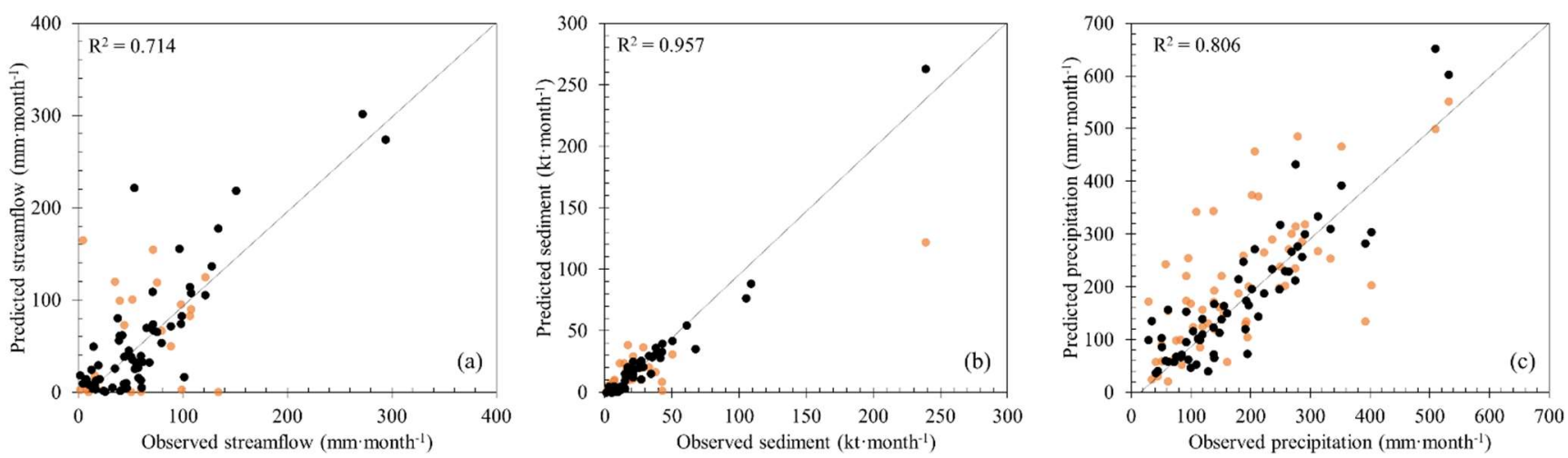

Figure 3. Goodness-of-fit plots with 1:1 line comparing the observed and simulated (a) streamflow, (b) sediment, and (c) precipitation with parameters before and after calibration during 2009-2013 at U-tapao canal gaging station. Presented $\mathrm{R}^{2}$ is after calibration, where the orange $(\bullet)$ and black dots $(\bullet)$ indicate the predicted data before and after calibration, respectively.

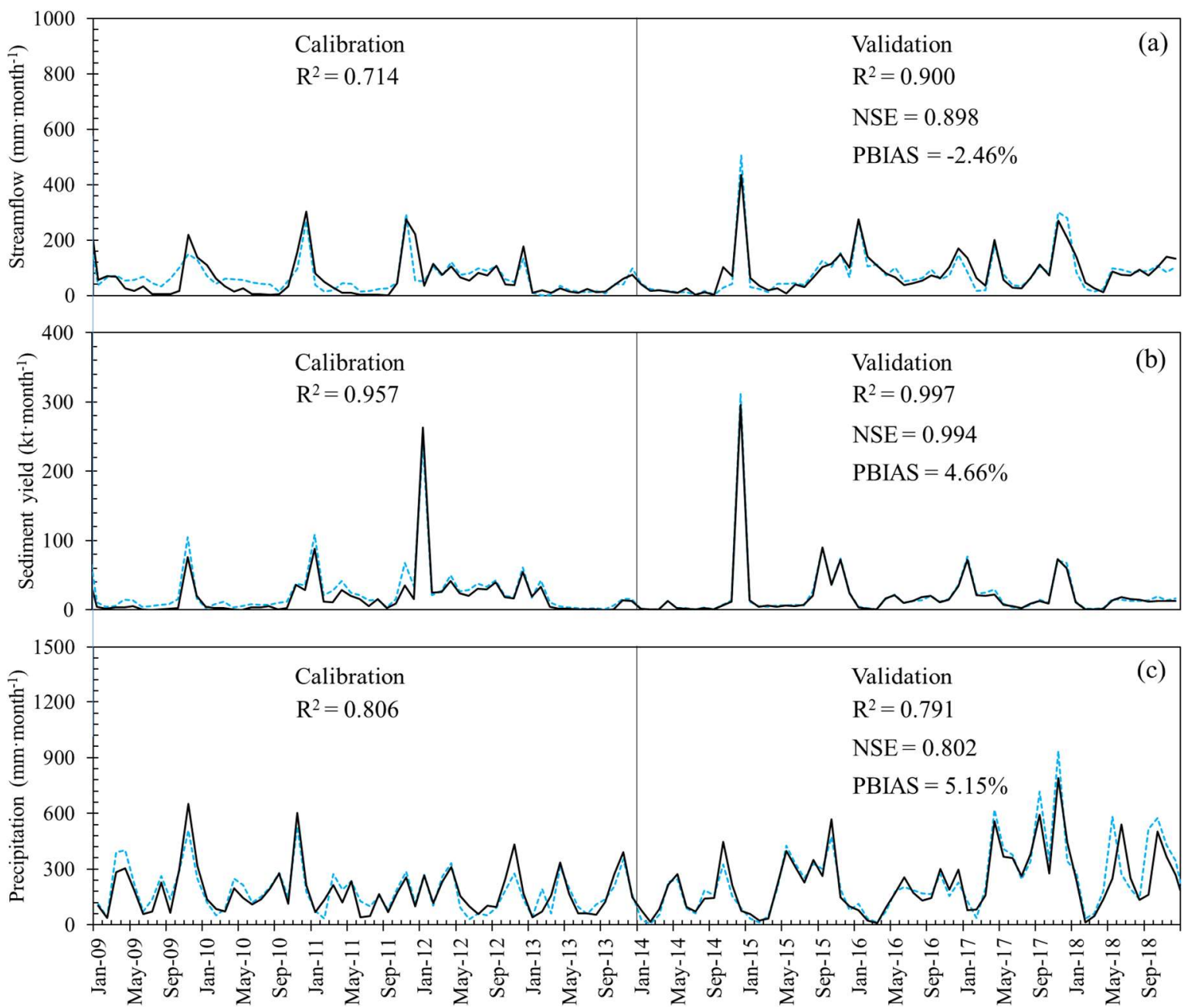

Figure 4. Model calibration and validation results for (a) streamflow, (b) sediment, and (c) precipitation at Songkhla Lake Basin at U-tapao canal gauging station, where the black solid line indicates the predicted data, and the blue dash line indicates the observed data.

To validate the generalization performance of the calibrated model, data from 2014 to 2018 were compared with the simulation data obtained from the parameter set obtained 
after the calibration. Figure 4 compares the temporal changes in the simulated and observed monthly streamflow, sediment yield, and precipitation obtained during calibration and validation. The results reveal that although some parts were over/underestimated, the model could reasonably predict the overall variation in streamflow, sediment yield, and precipitation. There was a slight concern regarding the accuracy of the weather data generated by the dGEN because precipitation data are generally recognized as the most important data for hydrological analysis. To ensure that the data were of adequate quality, careful validation was performed. It is clear that the precipitation data generated by dGEN resembled the actual historical data, as the dGEN could predict the precipitation data from 2013-2018, with an $\mathrm{R}^{2}$ of 0.791 , an NSE of 0.802 , and a PBIAS of $5.15 \%$.

With accurate weather data, it was found that the SWAT model can successfully and accurately estimate the streamflow during 2014-2018, with an $R^{2}$ of 0.900 , an NSE of 0.898 , and a PBIAS of $-2.46 \%$. The negative value of the PBAIS indicates that the model overestimated the streamflow by approximately $2.5 \%$ (on average). On the other hand, the sediment yield at the U-tapao canal gaging station during 2014-2018 can be estimated by the SWAT model with an $\mathrm{R}^{2}$ of 0.997 , an NSE of 0.994 , and a PBIAS of $4.66 \%$. The sediment yield was positive for the PBAIS, indicating that sediment yield was underestimated by approximately $4.7 \%$. Considering all the statistical indicators, the model is deemed adequate for investigating the effects of Napier grass plantations on hydrology and water quality.

\subsection{Impacts of Napier Grass Energy Plantation Cases}

The impacts of different levels of applied nitrogen fertilizer on Napier grass production, streamflow, sediment yield, and nitrate load were investigated over a period of 10 years. Figure 5 depict the spatial distribution of average Napier grass DMY planted with different nitrogen fertilizer levels in the abandoned area in SLB. The results, as shown in Figure 6, revealed that without applying the nitrogen fertilizer, the average DMY in the basin was approximately $11.28 \mathrm{t}$-DMY ha ${ }^{-1}$ (i.e., $663 \mathrm{kt}$-DMY in total); however, as the amount of applied nitrogen fertilizer increased, the DMY increased. The Napier grass DMY can be increased to 18.19, 22.71, and 27.52 t-DMY ha ${ }^{-1}$ after the application of nitrogen fertilizers of 125,250 , and $500 \mathrm{kgN} \mathrm{ha}^{-1}$, respectively. These results align with the hypothesis from Hazary et al. [42] that the fertilizer application rate positively affects the production of dedicated energy crops. The DMY increased by approximately $61 \%$ when the nitrogen fertilizer of $125 \mathrm{kgN} \mathrm{ha}^{-1}$ was applied; however, when the amount of fertilizer was doubled to $250 \mathrm{kgN} \mathrm{ha}^{-1}$, only a $25 \%$ increase in DMY was observed. An increase in the DMY of only $22 \%$ was achieved when the nitrogen fertilizer level was further increased to $500 \mathrm{kgN} \mathrm{ha}^{-1}$. Considering the diminishing return, it is unsurprising that a fertilizer level of $250 \mathrm{kgN} \mathrm{ha}^{-1}$ was recommended by the handbook from Nakhon Ratchasima Animal Nutrition Research and Development Center [55]. Although DMY was increased along with the amount of nitrogen fertilizer, it was not clear how it affected hydrology and water quality. Hence, it is important to investigate its effects on surface runoff, sediment yield, and nitrate load.

Figure 7 displays the simulated surface runoff, sediment load, and nitrate load obtained from the SWAT model. The surface runoff at the SLB for different cases was investigated, as shown in Figure 7a. It is clear that planting Napier grass in abandoned areas has a positive impact on surface runoff prevention. While reducing surface runoff may be beneficial for flood control, it can be considered detrimental for water resources and lake ecosystem health. This is due to the fact that the SLB is extremely prone to flooding and landslides. Thus, the decrease in surface runoff was considered to have a positive effect on the area. Surface runoff can be reduced by approximately $30 \%$ by Napier grass plantations. These results concur with the results of previous studies, that show that perennials can help reduce surface runoff $[24,56]$. This is due to the fact that most studies replaced row crops with perennials, and the perennials have better soil cover. In this study, abandoned areas were used in Napier grass plantations; based on Equations (1) and (2), the surface runoff $Q_{\text {surf }}$ is a function of the curve number. The curve number directly reflects the 
characteristic land cover and hydrologic soil groups. When the abandoned areas were replaced by Napier grass, the curve number decreased from 65 to 55, resulting in better water retention. The lower curve number is likely due to the large transpiration rate of the Napier grass. While the surface runoff greatly decreased with the Napier grass plantation, no significant differences between the case of different applied nitrogen fertilizer levels were observed. This is because the increase in the vertical growth of Napier grass did not affect the lateral soil coverage, which is a key factor in reducing surface runoff [28].

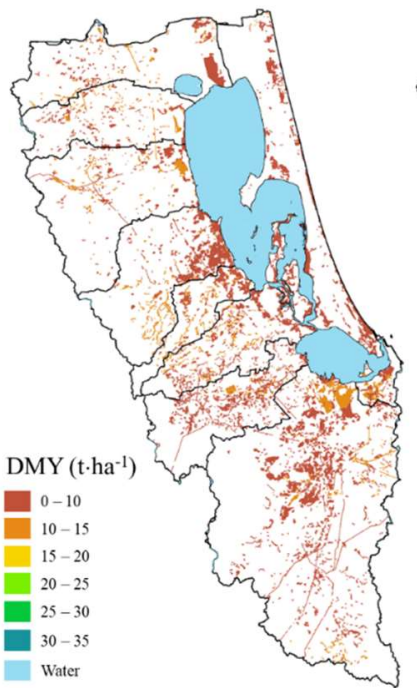

(a) $0 \mathrm{~kg}-\mathrm{N} \cdot \mathrm{ha}^{-1}$

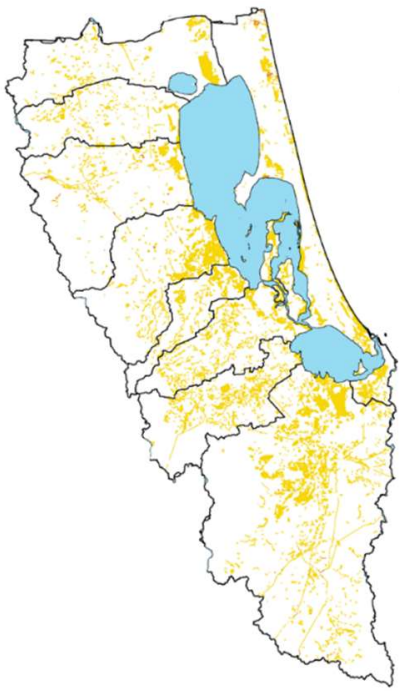

(b) $125 \mathrm{~kg}-\mathrm{N} \cdot \mathrm{ha}^{-1}$

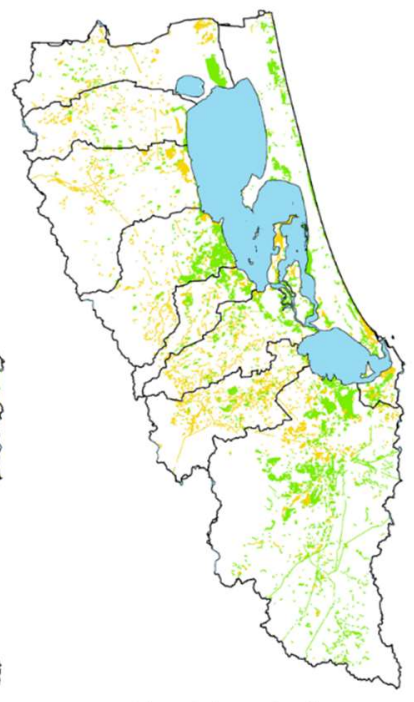

(c) $250 \mathrm{~kg}-\mathrm{N} \cdot \mathrm{ha}^{-1}$

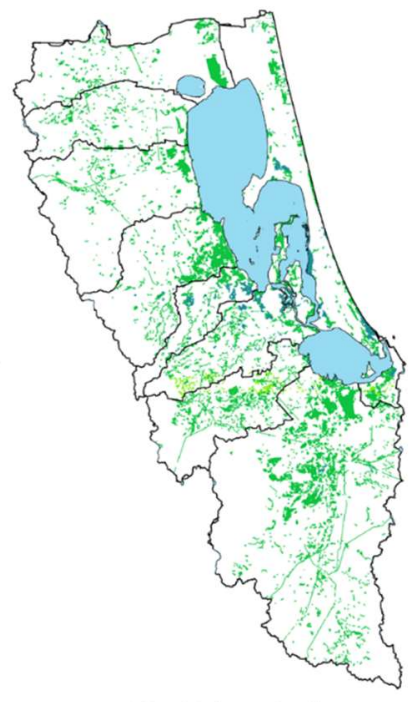

(d) $500 \mathrm{~kg}-\mathrm{N} \cdot \mathrm{ha}^{-1}$

Figure 5. Spatial distribution of Napier grass DMY from abandoned areas in Songkhla Lake Basin under different nitrogen fertilizer application levels of (a) 0 , (b) 125 , (c) 250 , and (d) $500 \mathrm{kgN} \mathrm{ha}^{-1}$.

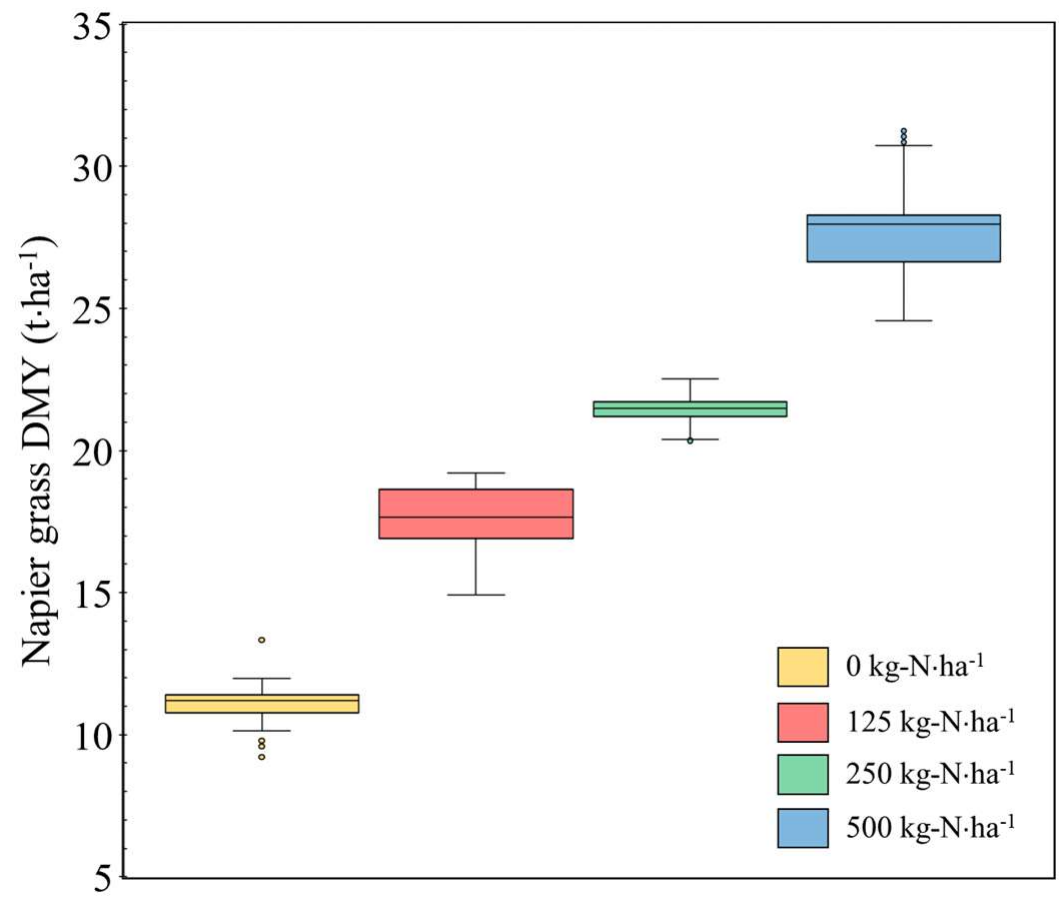

Figure 6. Box plots of Napier grass DMY from abandoned areas in Songkhla Lake Basin under different nitrogen fertilizers of $0,125,250$, and $500 \mathrm{kgN} \mathrm{ha}^{-1}$. 

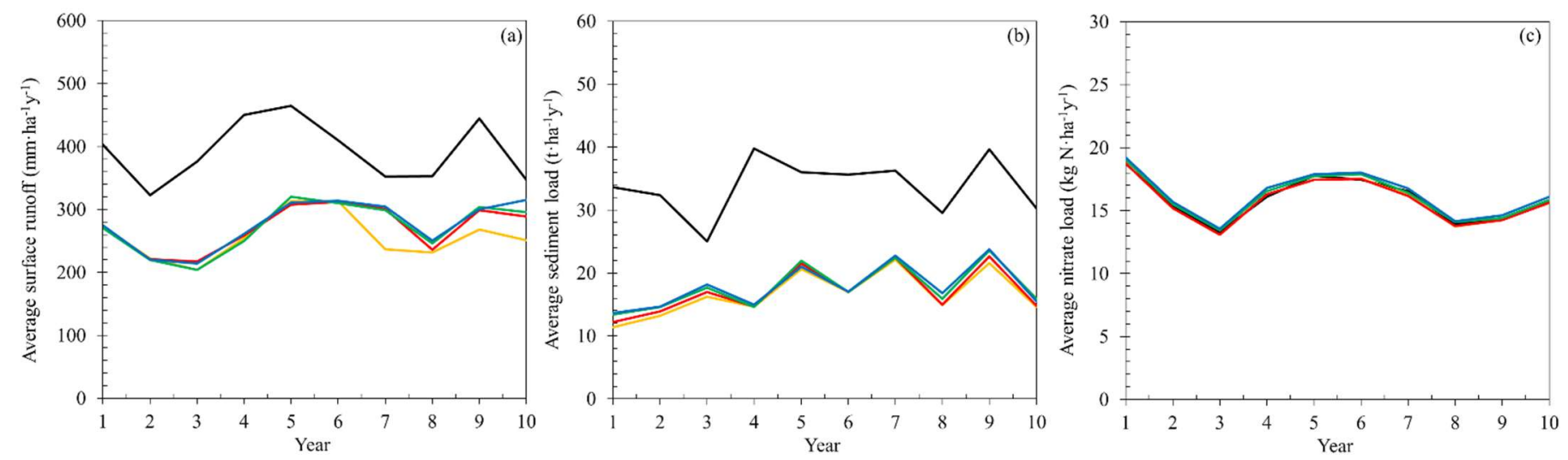

Figure 7. Average annual (a) surface runoff, (b) sediment load, and (c) nitrate load of Songkhla Lake Basin for 10 years timespan, where black, yellow, red, green, and blue solid lines indicate the baseline case and the Napier grass plantation cases with the nitrogen fertilizer applications of $0,125,250$, and $500 \mathrm{kgN} \mathrm{ha}^{-1}$, respectively.

Figure $7 \mathrm{~b}$ displays the sediment yield for the different planting scenarios at the SLB. The sediment yield decreased when abandoned areas were used for Napier grass plantations. This has a positive impact, as the sediment yield is strongly related to soil erosion. The decrease in sediment yields implied that water bodies would be less polluted by soil erosion; sediment yield was significantly reduced, by approximately $50 \%$. When different nitrogen fertilizer levels were applied, no significant differences were observed. These results were similar to those of the surface runoff presented above. It is unsurprising that the SWAT model utilizes the MUSLE equation (see Equation (3)), where the surface runoff volume and peak flow rate were used while calculating sediment yield. In addition to these two factors, the USLE cover and management factor $C$ are the only parameters that change with land use, which involves only the impacts of crop type and tillage method. Since the applied fertilizer level did not affect the USLE cover and management factor $C$, it is unsurprising that the sediment yield was not affected by the different fertilizer levels. It is worth noting that the USLE_C, which is the minimum USLE crop factor, is the same for abandoned areas as well as Napier grass plantations, as shown in Table 3. This is because the crop types considered in the abandoned and Napier grass plantation areas were the same. A USLE_C of 0.003 was suggested as a default value for perennials; however, the USLE cover and management factor $C$ could be different because it was calculated based on the USLE_C by considering the seasonal effects. Moreover, Singh et al. [57] suggested that the USLE cover and management factor $C$ are the least influential parameters in sediment yield calculation.

For the nitrate loads calculated as the sum of leaching and loading to the water stream by surface runoff and lateral flow, the average nitrate loads over SLB with different planting cases are shown in Figure 7c. The results revealed that the nitrate loads can be reduced slightly when fertilizer rates of 0 and $125 \mathrm{kgN} \mathrm{ha}^{-1}$ were applied. The reduction in nitrate loads is in agreement with the results of previous studies, which indicated that dedicated energy crops consume much nitrogen for growth [42]. In addition, several studies have shown that perennials can help reduce nitrate loads [24,25,58,59]; however, the nitrate loads increased slightly when the amount of applied nitrogen fertilizer exceeded $250 \mathrm{kgN} \mathrm{ha}^{-1}$. Although a large amount of nitrogen fertilizer was applied in the cultivation, the nitrate loads, as compared to the baseline (see above), increased by approximately $1.13 \%$ and $2.32 \%$ for the applied fertilizer rates of $250 \mathrm{kgN} \mathrm{ha}^{-1}$ and $500 \mathrm{kgN} \mathrm{ha}^{-1}$, respectively. This can be explained by the total nitrate balance summarized in Table 4. It is clear that nitrogen uptake by plants was the most influential nitrogen removal process. Because of diminishing returns, Napier grass cannot consume all the applied fertilizer for the case of 250 and $500 \mathrm{kgN} \mathrm{ha}^{-1}$, resulting in surplus nitrogen in the considered area. 
Table 4. Soil system nitrate balance of the baseline and Napier grass plantation cases with four fertilizer application levels in the SLB. Values are expressed per hectare of the whole basin $\left(\mathrm{kg}_{-} \mathrm{N} \mathrm{ha}{ }^{-1} \mathrm{y}^{-1}\right)$, including all land uses in the basin.

\begin{tabular}{|c|c|c|c|c|c|}
\hline \multirow{2}{*}{ Item } & \multirow{2}{*}{ Baseline } & \multicolumn{4}{|c|}{ Napier Grass Plantation } \\
\hline & & $0 \mathrm{kgN} \mathrm{ha}^{-1}$ & $125 \mathrm{kgN} \mathrm{ha}^{-1}$ & $250 \mathrm{kgN} \mathrm{ha}^{-1}$ & $500 \mathrm{kgN} \mathrm{ha}^{-1}$ \\
\hline \multicolumn{6}{|l|}{ Inputs } \\
\hline Fertilizer application & 39.88 & 39.88 & 42.90 & 47.15 & 51.88 \\
\hline Humus mineralization & 9.36 & 9.06 & 9.31 & 10.15 & 10.31 \\
\hline Residue mineralization & 6.78 & 6.37 & 6.76 & 8.12 & 8.94 \\
\hline Atmospheric deposition & 0.26 & 0.26 & 0.26 & 0.26 & 0.26 \\
\hline$\sum$ Inputs & 56.28 & 55.58 & 59.23 & 65.68 & 71.39 \\
\hline \multicolumn{6}{|l|}{ Outputs } \\
\hline Denitrification & 3.65 & 3.65 & 4.00 & 5.65 & 6.44 \\
\hline Nitrate uptake & 37.64 & 37.84 & 40.37 & 43.64 & 47.51 \\
\hline Nitrate leached & 13.86 & 13.34 & 13.86 & 14.53 & 14.58 \\
\hline $\begin{array}{l}\text { Nitrate loading to stream } \\
\text { in surface runoff }\end{array}$ & 1.19 & 1.16 & 1.20 & 1.29 & 1.38 \\
\hline $\begin{array}{l}\text { Nitrate loading to stream } \\
\text { in lateral flow }\end{array}$ & 0.04 & 0.04 & 0.04 & 0.04 & 0.04 \\
\hline$\sum$ Outputs & 56.39 & 56.03 & 59.47 & 65.15 & 69.95 \\
\hline$\sum$ Inputs $-\sum$ Outputs & -0.11 & -0.45 & -0.24 & 0.53 & 1.44 \\
\hline
\end{tabular}

To obtain a better basis for decision making, a multidisciplinary evaluation was carried out to compare the advantages and disadvantages of different planting cases. Figure 8 shows the radar chart of the evaluation indicators, including surface runoff, sediment yield, nitrate load, energy supply, farmer income, and $\mathrm{CO}_{2}$ reduction for different planting cases. The results revealed that although applying nitrogen fertilizers of $500 \mathrm{kgN} \mathrm{ha}^{-1}$ provided the highest benefits in energy supply, farmer's incomes, and $\mathrm{CO}_{2}$ reduction, it also performed the worst in hydrological indicators among the different planting cases considered in this study. Together with the case of $250 \mathrm{kgN} \mathrm{ha}^{-1}$ nitrogen fertilization, these were the only two cases that performed worse than the baseline upon increasing the amount of nitrate load into the system. On the other hand, without the applied fertilizer, benefits from Napier grass were in contrast with that of the case when nitrogen fertilization of $500 \mathrm{kgN} \mathrm{ha}^{-1}$ was applied. This suggests that there is a trade-off between hydrological indicators and other factors, including energy supply, farmer income, and $\mathrm{CO}_{2}$ reduction. The case in which nitrogen fertilization of $125 \mathrm{kgN} \mathrm{ha}^{-1}$ was applied would be a better choice as it was more balanced in all indicators.

Overall, from the simulated results of this study, Napier grass plantation in the abandoned land in SLB resulted in a decrease in surface runoff and sediment yield, which is beneficial to the water cycle control in SLB since the SLB is prone to flooding and landslides. In addition, nitrate loads were shown to be reduced in the Napier grass plantation cases with modest fertilizer applications. The socio-economic indicators supported utilizing abandoned areas in southern Thailand to plant Napier grass for biogas-based power generation, which can help reduce the dependency on imported electricity and provide additional income and/or job opportunities for local people. However, it should be noted that the decrease in surface runoff, sediment yield, and nitrate load does not always have a positive impact on ecosystem health in areas that are not susceptible to flooding and landslides. Therefore, prior to the introduction of new dedicated energy crops, it is important to assess the impacts on land, ecosystems, and other criteria unique to the area of interest. Although there are several potential benefits to be obtained from Napier grass plantations, it is unclear if the Napier grass-related businesses will be economically sustainable. In this study, the analysis was not quantitative because the importance of all evaluation indicators could not be adequately compared. Therefore, a further study on the economic perspective of introducing Napier grass as a biogas feedstock for power generation should be carried out; such a study is already ongoing within our research group. 


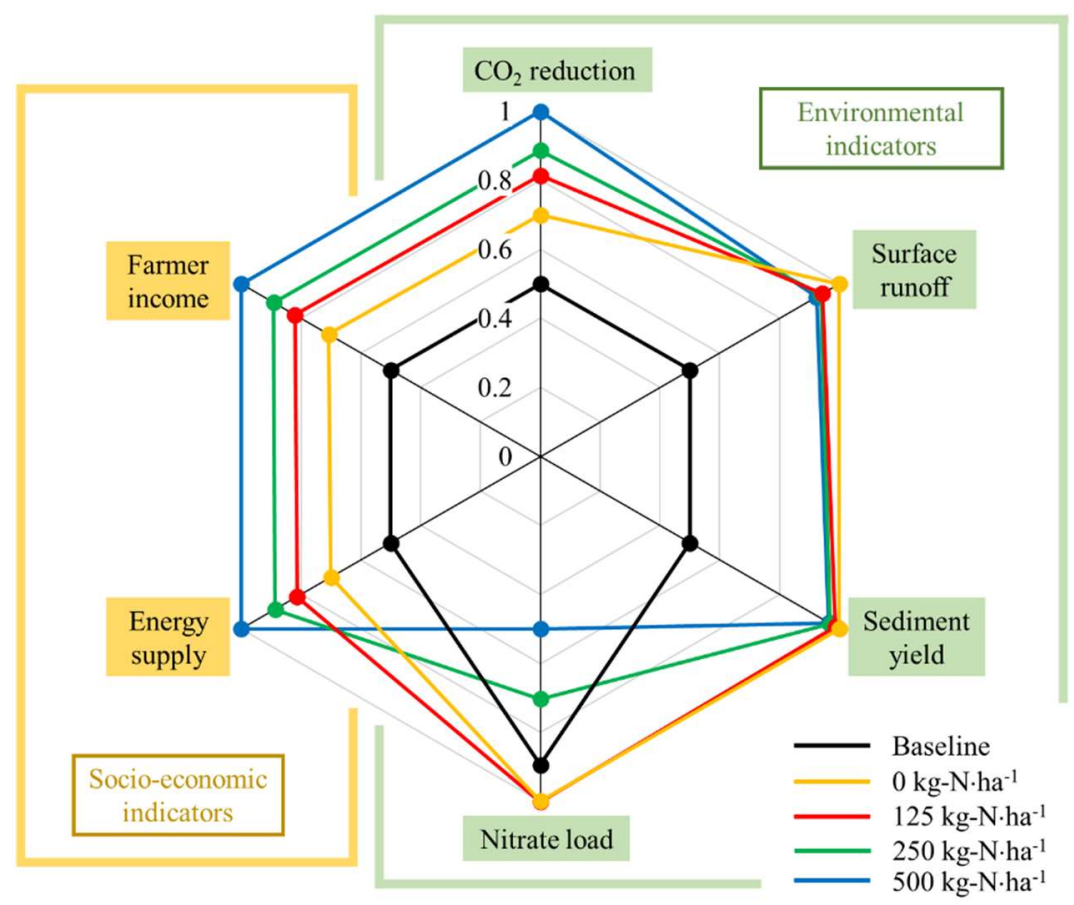

Figure 8. Comparison of the evaluation indicators of baseline and Napier grass plantation cases on surface runoff, sediment yield, nitrate load, energy supply, farmer income, and $\mathrm{CO}_{2}$ reduction. The indicators were scaled by the max-min normalization of the values, where max and min values were set to be 1.0 and 0.5 , respectively.

\section{Conclusions}

To introduce new crops for specific purposes, such as bio-energy resources, it is important to consider their impacts on environmental and socioeconomic benefits. In this study, a methodological framework for investigating the impacts of Napier grass plantations and a multidisciplinary assessment was successfully developed based on the SWAT watershed model. To obtain a reliable parameter set for the simulation, this model was carefully calibrated and validated. Utilizing manual calibration, a set of parameters used to predict streamflow, sediment yield, and nitrate load were obtained by considering the $\mathrm{R}^{2}$. The results showed that by planting Napier grass, surface runoff, sediment yield, and nitrate load can all be greatly reduced. This is because of the increase in land cover and the nature of Napier grass, which consumes a large amount of nitrogen. The increase in nitrogen fertilizer was found to be relatively insignificant to overall surface runoff and sediment yield; however, the amount of $\mathrm{N}$ fertilizer significantly affected the nitrate load - as the nitrogen fertilizer level increased, the nitrate load increased. To have a clearer idea of how different cases impacted other perspectives, energy supply, farmer's incomes, and $\mathrm{CO}_{2}$ reduction were included as further considerations. The results of this consideration revealed that when no fertilizers were applied, the management practice performed best in reducing the negative impacts on hydrology and water quality. However, applying fertilizer as high as $500 \mathrm{kgN} \mathrm{ha}^{-1}$ provided the highest energy supply, income to farmers, and $\mathrm{CO}_{2}$ reduction. The results of this study provide information about the environmental impacts as well as crop production. This is supportive for both energy-related policymakers and farmers, since policymakers can utilize this information to consider a tradeoff between environmental impacts and crop production, and the farmers can learn how to achieve high comprehensive benefits from their crops.

Author Contributions: Conceptualization, K.N. and T.M.; methodology, K.N.; software, K.N.; validation, K.N.; formal analysis, K.N. and T.M.; investigation, K.N. and P.C.-a.; resources, K.N.; data curation, K.N.; writing-original draft preparation, K.N.; writing-review and editing, P.C.-a. and T.M.; visualization, P.C.-a.; supervision, T.M. and K.H.; funding acquisition, K.H. All authors have read and agreed to the published version of the manuscript. 
Funding: This work was carried out by the joint research program of the Institute of Materials and Systems for Sustainability, Nagoya University.

Acknowledgments: Gives thanks to the fund.

Conflicts of Interest: The authors declare no conflict of interest.

\section{References}

1. Höhn, J.; Lehtonen, E.; Rasi, S.; Rintala, J. A Geographical Information System (GIS) based methodology for determination of potential biomasses and sites for biogas plants in southern Finland. Appl. Energy. 2014, 113, 1-10. [CrossRef]

2. Chukwuma, E.C.; Okey-Onyesolu, F.C.; Ani, K.A.; Nwanna, E.C. Gis bio-waste assessment and suitability analysis for biogas power plant: A case study of Anambra state of Nigeria. Renew. Energy 2020, 163, 1182-1194. [CrossRef]

3. Piekutin, J.; Puchlik, M.; Haczykowski, M.; Dyczewska, K. The Efficiency of the Biogas Plant Operation Depending on the Substrate Used. Energies 2021, 14, 3157. [CrossRef]

4. Paine, L.K.; Peterson, T.L.; Undersander, D.J.; Rineer, K.C.; Bartelt, G.A.; Temple, S.A.; Sample, D.W.; Klemme, R.M. Some ecological and socio-economic considerations for biomass energy crop production. Biomass Bioenergy 1996, 10, 231-242. [CrossRef]

5. Shahpari, S.; Allison, J.; Harrison, M.T.; Stanley, R. An Integrated Economic, Environmental and Social Approach to Agricultural Land-Use Planning. Land 2021, 10, 364. [CrossRef]

6. Cervelli, E.; Scotto di Perta, E.; Pindozzi, S. Energy crops in marginal areas: Scenario-based assessment through ecosystem services, as support to sustainable development. Ecol. Indic. 2020, 113, 106180. [CrossRef]

7. Li, J.; Zhang, Z.; Jin, X.; Chen, J.; Zhang, S.; He, Z.; Li, S.; He, Z.; Zhang, H.; Xiao, H. Exploring the socioeconomic and ecological consequences of cash crop cultivation for policy implications. Land Use Policy 2018, 76, 46-57. [CrossRef]

8. Sinbuathong, N.; Sangsil, Y.; Sawanon, S. Energy, Transportation and Global Warming; Springer: Berlin/Heidelberg, Germany, 2016.

9. Sawasdee, V.; Pisutpaisal, N. Feasibility of Biogas Production from Napier Grass. Energy Procedia 2014, 61, 1229-1233. [CrossRef]

10. Dussadee, N.; Ramaraj, R.; Cheunbarn, T. Biotechnological application of sustainable biogas production through dry anaerobic digestion of Napier grass. 3 Biotech 2017, 7, 47. [CrossRef]

11. Prapinagsorn, W.; Sittijunda, S.; Reungsang, A. Co-Digestion of Napier Grass and Its Silage with Cow Dung for Bio-Hydrogen and Methane Production by Two-Stage Anaerobic Digestion Process. Energies 2017, 11, 47. [CrossRef]

12. Bach, E.E.; Alcântara, V.B.G.; Alcântara, P.B.; Veasey, E.A. Biochemical and isoenzyme analyses of elephant grass, Pennisetum purpureum (Schum) varieties. Sci. Agric. 1995, 52, 528. [CrossRef]

13. Janejadkarn, A.; Chavalparit, O. Biogas Production from Napier Grass (Pak Chong 1) (Pennisetum purpureum $\times$ Pennisetum americanum). Adv. Mat. Res. 2013, 856, 327-332. [CrossRef]

14. Napier Grass. Available online: http://weben.dede.go.th/webmax/content/napier-grass (accessed on 5 September 2021).

15. Negawo, A.T.; Teshome, A.; Kumar, A.; Hanson, J.; Jones, C.S. Opportunities for Napier Grass (Pennisetum purpureum) Improvement Using Molecular Genetics. Agronomy 2017, 7, 28. [CrossRef]

16. Anderson, W.F.; Sarath, G.; Edme, S.; Casler, M.D.; Mitchell, R.B.; Tobias, C.M.; Hale, A.L.; Sattler, S.E.; Knoll, J.E. Dedicated Herbaceous Biomass Feedstock Genetics and Development. BioEnergy Res. 2006, 9, 399-411. [CrossRef]

17. Nelson, R.G.; Ascough, J.C.; Langemeier, M.R. Environmental and economic analysis of switchgrass production for water quality improvement in northeast Kansas. J. Environ. Manag. 2006, 79, 336-347. [CrossRef] [PubMed]

18. Pincam, T.; Brix, H.; Eller, F.; Jampeetong, A. Hybrid Napier grass as a candidate species for bio-energy in plant-based water treatment systems: Interactive effects of nitrogen and water depth. Aquat. Bot. 2017, 138, 82-91. [CrossRef]

19. Börjesson, P. Environmental effects of energy crop cultivation in Sweden-I: Identification and quantification. Biomass Bioenergy 1999, 16, 137-154. [CrossRef]

20. Njakou Djomo, S.; Ac, A.; Zenone, T.; De Groote, T.; Bergante, S.; Facciotto, G.; Sixto, H.; Ciria Ciria, P.; Weger, J.; Ceulemans, R. Energy performances of intensive and extensive short rotation cropping systems for woody biomass production in the EU. Renew. Sust. Energy Rev. 2015, 41, 845-854. [CrossRef]

21. Vatsanidou, A.; Kavalaris, C.; Fountas, S.; Katsoulas, N.; Gemtos, T. A Life Cycle Assessment of Biomass Production from Energy Crops in Crop Rotation Using Different Tillage System. Sustainability 2020, 12, 6978. [CrossRef]

22. Dos Santos, F.M.; Proença de Oliveira, R.; Augusto Di Lollo, J. Effects of Land Use Changes on Streamflow and Sediment Yield in Atibaia River Basin-SP, Brazil. Water 2020, 12, 1711. [CrossRef]

23. Epelde, A.M.; Cerro, I.; Sánchez-Pérez, J.M.; Sauvage, S.; Srinivasan, R.; Antigüedad, I. Application of the SWAT model to assess the impact of changes in agricultural management practices on water quality. Hydrol. Sci. J. 2015, 60, 825-843. [CrossRef]

24. Ng, T.L.; Eheart, J.W.; Cai, X.; Miguez, F. Modeling Miscanthus in the Soil and Water Assessment Tool (SWAT) to Simulate Its Water Quality Effects as a Bioenergy Crop. Environ. Sci. Technol. 2010, 44, 7138-7144. [CrossRef]

25. Cibin, R.; Trybula, E.; Chaubey, I.; Brouder, S.M.; Volenec, J.J. Watershed-scale impacts of bioenergy crops on hydrology and water quality using improved SWAT model. Glob. Change Biol. 2016, 8, 837-848. [CrossRef]

26. Nantasaksiri, K.; Charoen-Amornkitt, P.; Machimura, T. Land Potential Assessment of Napier Grass Plantation for Power Generation in Thailand Using SWAT Model. Model Validation and Parameter Calibration. Energies 2021, 14, 1326. [CrossRef] 
27. Nantasaksiri, K.; Charoen-Amornkitt, P.; Machimura, T. Integration of multicriteria decision analysis and geographic information system for site suitability assessment of Napier grass-based biogas power plant in southern Thailand. Renew. Sust. Energ. 2021, 1, 100011. [CrossRef]

28. Somboonsuke, B.; Phitthayaphinant, P.; Sdoodee, S.; Kongmanee, C. Farmers' perceptions of impacts of climate variability on agriculture and adaptation strategies in Songkhla Lake basin. Kasetsart J. Soc. Sci. 2018, 39, 277-283. [CrossRef]

29. Cookey, P.E.; Darnswasdi, R.; Ratanachai, C. Local people's perceptions of Lake Basin water governance performance in Thailand. Ocean. Coast. Manag. 2016, 120, 11-28. [CrossRef]

30. Soil and Water Assessment Tool SWAT, Theoretical Documentation. Available online: https://swat.tamu.edu/media/1292/SWAT2 005theory.pdf (accessed on 10 August 2021).

31. Hass, M.B.; Guse, B.; Pfannerstill, M.; Fohrer, N. Detection of dominant nitrate processes in ecohydrological modeling with temporal parameter sensitivity analysis. Ecol. Model. 2015, 314, 62-72. [CrossRef]

32. Farr, T.G.; Rosen, P.A.; Caro, E.; Crippen, R.; Duren, R.; Hensley, S.; Michael, K.; Mimi, P.; Ernesto, R.; Ladislav, R.; et al. The Shuttle Radar Topography Mission. Rev. Geophys. 2007, 45, RG2004. [CrossRef]

33. Fischer, G.; Nachtergaele, F.O.; Prieler, S.; Teixeira, E.; Tóth, G.; van Velthuizen, H.; Verelst, L.; Wiberg, D. Global Agro-Ecological Zones (GAEZ v3.0): Model Documentation; IIASA: Laxenburg, Austria; FAO: Rome, Italy, 2012; p. 179.

34. NCEP Climate Forecast System Reanalysis (CFRS). Available online: http:/ / globalweather.tamu.edu/ (accessed on 23 August 2021).

35. Senent-Aparicio, K.; Jimeno-Sáez, P.; López-Ballesteros, A.; Ginés Giménez, J.; Pérez-Sánchez, J.; Cecilia, J.M.; Srinivasan, R. Impacts of swat weather generator statistics from high-resolution datasets on monthly streamflow simulation over Peninsular Spain. J. Hydrol. Reg. Stud. 2021, 35, 100826. [CrossRef]

36. Uniyal, B.; Dietrich, J.; Vu, N.Q.; Jha, M.K.; Luis Arumí, J. Simulation of regional irrigation requirement with SWAT in different agro-climatic zones driven by observed climate and two re-analysis datasets. Sci. Total Environ. 2019, 649, 846-865. [CrossRef]

37. Himanshu, S.K.; Pandey, A.; Yadav, B.; Gupta, A. Evaluation of best management practices for sediment and nutrient loss control using SWAT model. Soil Tillage Res. 2019, 192, 42-58. [CrossRef]

38. Ruan, H.; Zou, S.; Yang, D.; Wang, Y.; Yin, Z.; Lu, Z.; Li, F.; Xu, B. Runoff Simulation by SWAT Model Using High-Resolution Gridded Precipitation in the Upper Heihe River Basin, Northeastern Tibetan Plateau. Water 2017, 9, 866. [CrossRef]

39. Abbaspour, K.C.; Yang, J.; Maximov, I.; Siber, R.; Bogner, K.; Mieleitner, J.; Zobrist, J.; Srinivasan, R. Modelling hydrology and water quality in the pre-alpine/alpine Thur watershed using SWAT. J. Hydrol. 2007, 333, 413-430. [CrossRef]

40. Mengistu, A.G.; van Rensburg, L.D.; Woyessa, Y.E. Techniques for calibration and validation of SWAT model in data scarce arid and semi-arid catchments in South Africa. J. Hydrol. Reg. Stud. 2019, 25, 100621. [CrossRef]

41. Arnold, J.G.; Moriasi, D.N.; Gassman, P.W.; Abbaspour, K.C.; White, M.J.; Srinivasan, R.; Santhi, C.; Harmel, R.D.; van Griensven, A.; Van Liew, M.W.; et al. SWAT: Model use, calibration, and validation. Trans. ASABE 2012, 55, 1491-1508. [CrossRef]

42. Hazary, M.E.H.; Bilkis, T.; Khandaker, Z.H.; Akbar, M.A.; Khaleduzzaman, A.B.M. Effect of nitrogen and phosphorus fertilizer on yield and nutritional quality of Jumbo Grass (Sorghum Grass $\times$ Sudan Grass). Adv. Anim. Vet. Sci. 2015, 3, 444-450. [CrossRef]

43. Phaikeaw, C.; Phunphiphat, W.; Phunpiphat, R.; Kulna, S. Effect of Rate and Application time of Nitrogen Fertilizer on Forage Yield and Chemical Composition of Dwarf Napier Grass in Sukhothai Province. In Annual Report of Bereau Animal Nutrition Development 2004; Thai National AGRIS Centre: Bangkok, Thailand, 2004; pp. 45-54.

44. Vuthiprachumpai, L.; Nakamanee, G.; Punpipat, W.; Monchaikul, S. Effect of Plant Spacings on Yield and Chemical Com-position of Napier Grass (Pennisetum purpureum), Dwarf Elephant Grass (P. purpureum cv. Mott) and King Grass (P. pur-pureum x P. americanum) at Chainat Province. In Annual Report of Bureau Animal Nutrition Development 1998; Thai National AGRIS Centre: Bangkok, Thailand, 1998; pp. 194-228.

45. Suksaran, W.; Nuntachomchoun, P.; Vongpipatana, C. Yield and Cheimcal Compositions of Napier Grass in Various locations II Effect of Cutting Interval on Yield and Chemical Compositions of Three Varieties of Napier Grass (2.4) in Petchabun Province. In Annual Report of Bureau Animal Nutrition Development 1991; Thai National AGRIS Centre: Bangkok, Thailand, 1991; pp. 41-53.

46. Klum-Em, K.; Pojun, S.; Thammasal, P. Effect of Rate and Application Period of Nitrogen Fertilizer on Yield and Chemical Composition of Dwarf Napier Grass in Sa Kaeo Province. In Annual Report of Bureau Animal Nutrition Development 2002; Thai National AGRIS Centre: Bangkok, Thailand, 2002; pp. 159-174.

47. Waipanya, S.; Kulna, S.; Suriyachaiwatana, I.; Srichoo, C. Effect of Plant Spacing on Yield and Chemical Composition of 3 Varieties of Napier Grass in Nakhonpanom Province. In Annual Report of Bureau Animal Nutrition Development 2003; Thai National AGRIS Centre: Bangkok, Thailand, 2003; pp. 32-42.

48. Chainosaeng, W.; Nuntachomchoun, P.; Suksaran, W. Yield and Chemical Compositions of Napier Grass in Various Locations Effect of Plant Spacing on Yield and Chemical Compositions of Three Varieties of Napier Grass (1.4) in Petchabun Province. In Annual Report of Bureau of Animal Nutrition Development 2004; Thai National AGRIS Centre: Bangkok, Thailand, 2004; pp. 26-40.

49. Chubisaeng, W.; Bhokasawat, K.; Intarit, S.; Wongpipat, C. Effect of Rate and Application Time of Nitrogen Fertilizaer on Yield and Chemical Composition of Dwarf Napier Grass in Renu Soil Series. In Annual Report of Bureau Animal Nutrition Development 2004; Thai National AGRIS Centre: Bangkok, Thailand, 2004; pp. 55-78.

50. Yuthavoravit, C.; Suksaran, W.; Paotong, S. Effect of Rate and Application Time of Nitrogen Fertilizer on Yield and Chemical Composition of Dwarf Napier Grass in Hub-Kapong Soil Series. In Annual Report of Bureau Animal Nutrition Development 2004; Thai National AGRIS Centre: Bangkok, Thailand, 2004; pp. 79-102. 
51. Phunphiphat, W.; Phunphiphat, R.; Kulna, S. Study on cost of production and forage yield of Dwarf Napeir Under Intensive Management. In Annual Report of Bureau Animal Nutrition Development 2005; Thai National AGRIS Centre: Bangkok, Thailand, 2005; pp. 87-99.

52. Tudose, N.C.; Marin, M.; Cheval, S.; Ungurean, C.; Davidescu, S.O.; Tudose, O.N.; Mihalache, A.L.; Davidescu, A.A. SWAT Model Adaptability to a Small Mountainous Forested Watershed in Central Romania. Forests 2021, 12, 860. [CrossRef]

53. Bossel, U.; Eliasson, B.; Taylor, G. The Future of the Hydrogen Economy: Bright or Bleak? Distrib. Gener. Altern. Energy J. 2003, 18, 29-70. [CrossRef]

54. Krittayakasem, P.; Patumsawad, S.; Garivait, S. Emission Inventory of Electricity Generation in Thailand. JSEE 2011, 2, 65-69.

55. Kiyothong, K. Handbook of Napier Grass CV. Pakchong 1 Plantation; Mittrapap Printing Ltd.: Nakhon Ratchasima, Thailand, 2011.

56. Dalzell, B.J.; Mulla, D.J. Perennial vegetation impacts on stream discharge and channel sources of sediment in the Minnesota River Basin. J. Soil Water Conserv. 2018, 73, 120-132. [CrossRef]

57. Singh, A.; Imtiyaz, M.; Isaac, R.K.; Denis, D.M. Assessing the performance and uncertainty analysis of the SWAT and RBNN models for simulation of sediment yield in the Nagwa watershed, India. Hydrol. Sci. J. 2014, 59, 351-364. [CrossRef]

58. Christianson, L.E.; Frankenberger, J.; Hay, C.; Helmers, M.J.; Sands, G. Ten Ways to Reduce Nitrogen Loads from Drained Cropland in the Midwest; University of Illinois Extension: Urbana, IL, USA, 2016.

59. Zhou, X.; Helmers, M.J.; Asbjornsen, H.; Kolka, R.; Tomer, M.D. Perennial Filter Strips Reduce Nitrate Levels in Soil and Shallow Groundwater after Grassland-to-Cropland Conversion. J. Environ. Qual. 2010, 39, 2006-2015. [CrossRef] [PubMed] 